\title{
Long-term acoustical observations of the mesopelagic fish Maurolicus muelleri reveal novel and varied vertical migration patterns
}

\author{
Arved Staby $^{1, *}$, Anders Røstad $^{2,3}$, Stein Kaartvedt ${ }^{2,3}$ \\ ${ }^{1}$ University of Bergen, Department of Biology, PO Box 7803, 5020 Bergen, Norway \\ ${ }^{2}$ University of Oslo, Department of Biology, PO Box 1066 Blindern, 0316 Oslo, Norway \\ ${ }^{3}$ King Abdullah University of Science and Technology, Saudi Arabia
}

\begin{abstract}
We studied the temporal dynamics in the vertical distribution of Maurolicus muelleri scattering layers (SL) by examining continuous acoustic recordings over a 15 mo period in Masfjorden, Norway, complemented by intermittent sampling campaigns. The data revealed known patterns as normal diel vertical migration (DVM), midnight sinking between dusk and dawn, and periods without migrations, as well as novel behaviours consisting of early morning ascents, reverse diel vertical migrations, and interrupted ascents in the evening. During the first autumn of the study, adult fish modified their normal DVM behaviour by suspending their migration in the evening, yet ascending toward the surface in the later part of the night to reach upper layers during dawn. This behaviour was not observed during the second autumn of the study. By mid- to end of November (1st autumn), adult fish had suspended the nocturnal ascent entirely, and in the subsequent period until the end of January, a fraction of the population rather performed limited reverse migrations, slightly shifting their vertical distribution upwards during the first part of the day. From January to March 2008, fish interrupted their evening ascent at apparently random intervals and returned to deeper waters, instead of completing a full ascent to the surface. Our study underlines the value of long-term recordings, with the results suggesting that $M$. muelleri has the capability of changing its behaviour in response to ontogeny and internal state (satiation and hunger) as well as to external stimuli.
\end{abstract}

KEY WORDS: Diel vertical migration · DVM · Scattering layers · Maurolicus muelleri · Ontogeny · Stationary hydroacoustics

\section{INTRODUCTION}

A variety of marine animals perform diel vertical migrations (DVM), including zooplankton, mesopelagic micronekton and planktivorous and piscivorous fish (Roe 1983, Kaartvedt et al. 1988, Neilson \& Perry 1990, Ringelberg 1991, Williams \& Koslow 1997, Onsrud \& Kaartvedt 1998, Frank \& Widder 2002, Cohen \& Forward 2009). Two basic types of DVM patterns are identified: in Type I migrations, organisms ascend to the surface before the onset of night (dusk) and down to daytime depths with day break (dawn), although nocturnal vertical relocations between dusk and dawn ('midnight sinking') can occur (Giske et al. 1990, Tarling et al. 2002, BenoitBird et al. 2009). In the reverse Type II migrations, organisms ascend in daytime and descend at night (Neilson \& Perry 1990). Light is considered an important proximate factor in DVM, and changes in both absolute and relative light intensity influence the depth distribution of organisms, their migration speed, and the timing of their ascent to and descent 
from the surface (Neilson \& Perry 1990, Baliño \& Aksnes 1993, Widder \& Frank 2001, Cohen \& Forward 2009, Staby \& Aksnes 2011).

Several hypotheses for vertical migrations on a population level have been put forward. Eggers (1978) proposed that the adaptive value of vertical migrations was to minimise predation risk by avoiding predators. The predator avoidance hypothesis was later extended to include the optimisation of foraging in the anti-predation window at intermediate light intensities at dusk and dawn (Clark \& Levy 1988, Scheuerell \& Schindler 2003). The bioenergetic efficiency hypothesis states that organisms distribute at temperatures which maximise growth (Wurtsbaugh \& Neverman 1988, Giske \& Aksnes 1992, Bevelhimer \& Adams 1993), while the foragingopportunity hypothesis predicts that the depth distribution of the predator overlaps with depth changes of its prey (Levy 1990a, Neilson \& Perry 1990). On an individual level, the hunger-satiation hypothesis assumes that vertical movements of individuals are triggered by a change in their hunger or satiation state (Pearre 2003).

Mueller's pearlside Maurolicus muelleri Gmelin 1789, a small mesopelagic fish (standard length $\sim 6 \mathrm{~cm}$, Rasmussen \& Giske 1994), displays DVM behaviour for the largest part of its life (3 to 5 yr, Gjøsæter 1981, Kristoffersen \& Salvanes 1998, Hamre 1999). However, in Norwegian fjords the vertical distribution behaviour of this species varies with ontogeny and season (Giske et al. 1990, Baliño \& Aksnes 1993, Rasmussen \& Giske 1994, Bjelland 1995, Goodson et al. 1995, Kaartvedt et al. 1998). Juveniles perform DVM in winter (Giske et al. 1990, Goodson et al. 1995) and feed on shallow distributed zooplankton during dusk and dawn periods (Rasmussen \& Giske 1994, Bagøien et al. 2001). When feeding during the crepuscular periods, juveniles seemingly exploit the antipredation window by foraging at light levels which optimise the trade-off between feeding and minimising predation risk (Clark \& Levy 1988, Rosland 1997). In winter and the beginning of spring, juveniles display midnight sinking behaviour after dusk (Giske et al. 1990, Goodson et al. 1995), distributing at deeper depths which may correspond with the temperature maximum (Giske et al. 1990, Giske \& Aksnes 1992). Adult fish carry out DVM during the productive season (March to September; Lopes 1979, Rasmussen \& Giske 1994, Goodson et al. 1995), but remain in deeper waters and suppress DVM in winter (Giske et al. 1990, Baliño \& Aksnes 1993, Goodson et al. 1995). By overwintering at deeper depths, adults most likely reduce predation risk in order to increase survival until the next spawning season (Rosland \& Giske 1994, Rosland 1997). On light/ dusky summer nights, dielly migrating $M$. muelleri avoid the uppermost layers and may reduce predation risk by schooling (Kaartvedt et al. 1998). The main predators of $M$. muelleri in Norwegian waters are gadoids like blue whiting Micromesistious potassou, saithe Pollachius virens, haddock Melanogrammus aeglefinus and pollack Pollachius pollachius (Giske et al. 1990, Salvanes \& Nordeide 1993, Rasmussen \& Giske 1994, Bjelland 1995, Staby 2010). Their vertical distribution may change dielly and seasonally (Staby 2010).

Although the DVM behaviour of Maurolicus muelleri is believed to be well understood, especially in the winter period, with behaviours explained in terms of ontogeny and as a trade-off between feeding and predation risk, most field studies of $M$. muelleri have only covered time spans of a few days. Consequently, few data are available on short-term (weeks) and long-term variations (months or years) in behaviour, apart from the main seasonal patterns outlined above.

The lack of long-term data can now be accommodated by new methodological approaches. Increasingly, acoustic data obtained with stationary echosounders are being used to study the behaviour of aquatic organisms (Axenrot et al. 2004, Mehner 2006, Didrikas \& Hansson 2009, Kaartvedt et al. 2009). Maurolicus muelleri already has a gas-filled swimbladder at the post-larval stage $(\sim 10 \mathrm{~mm})$ and forms acoustically visible scattering layers (SLs). The species is abundant in fjords (Giske et al. 1990), and thus close to land. This simplifies the logistics, and the use of relatively simple, autonomous acoustic setups for uninterrupted observations over long time periods is achievable (Kaartvedt et al. 2009). In the present study, we applied an upward facing echosounder, mounted on the bottom at approximately $390 \mathrm{~m}$ depth in Masfjorden, Norway, where acoustic scattering layers of $M$. muelleri have been identified from numerous previous studies (e.g. Giske et al. 1990, Baliño \& Aksnes 1993, Bagøien et al. 2001). The echosounder was cabled to shore for continuous power supply and transfer of data, and was operated for a 15 mo period. The continuous acoustic measurements were supplemented by continuous surface irradiance measurements on land for most of the recording period and intermittent field campaigns. This approach provided new insights into the migration dynamics of the $M$. muelleri population, and here we describe a flexible behavioural repertoire, including several novel migration patterns of $M$. muelleri SLs. 


\section{MATERIALS AND METHODS}

The study site was a basin in Masfjorden $\left(60^{\circ} 52^{\prime}\right.$ $77^{\prime \prime}$ N, $5^{\circ} 27^{\prime} 07^{\prime \prime}$ E), Norway (Fig. 1, see also Kaartvedt et al. 1988 where the study site is described in more detail). Hydroacoustic data were collected at a depth of $392 \mathrm{~m}$ between 1 July 2007 and 7 October 2008, apart from periods where the system stopped due to power failures (226 complete days were recorded in total). An upward facing Simrad EK60 $38 \mathrm{kHz}$ splitbeam echosounder, rigged on a stainless steel frame, was positioned on the fjord bottom and connected to a land-based laptop via a $1200 \mathrm{~m}$ long cable, which also supplied electricity and supported real-time data transfer. The pinging rate was set at $0.9 \mathrm{~s}^{-1}$, and the pulse duration was $0.512 \mathrm{~ms}$. A detailed description of the set-up is provided in Kaartvedt et al. (2009).

Echograms were visualised with MATLAB, and data from 2 subsequent days from each month were selected to highlight prevailing patterns. The minimum post processing volume backscattering strength $(\mathrm{Sv}, \mathrm{dB})$ threshold in MATLAB echograms was set at $-80 \mathrm{~dB}$, and the vertical migration behaviour of identified SLs was analysed based on these echograms. In most months, 2 different Maurolicus muelleri SLs could be distinguished, and for simplicity, we refer to the deepest SL as DSL and the shallowest SL as SSL. Sporadically, a third layer was observed above the SSL, which we identified as consisting of $M$. muelleri post-larvae. The upper and lower depth limits of the DSL at 13:00 h local time (12:00 h UTC) were visually determined in Echoview (Myriax) at a Sv threshold of $-75 \mathrm{db}$. The time of arrival at and departure from the surface of M. muelleri was established when the upper edge of the migrating layer was $5 \mathrm{~m}$ below the surface.

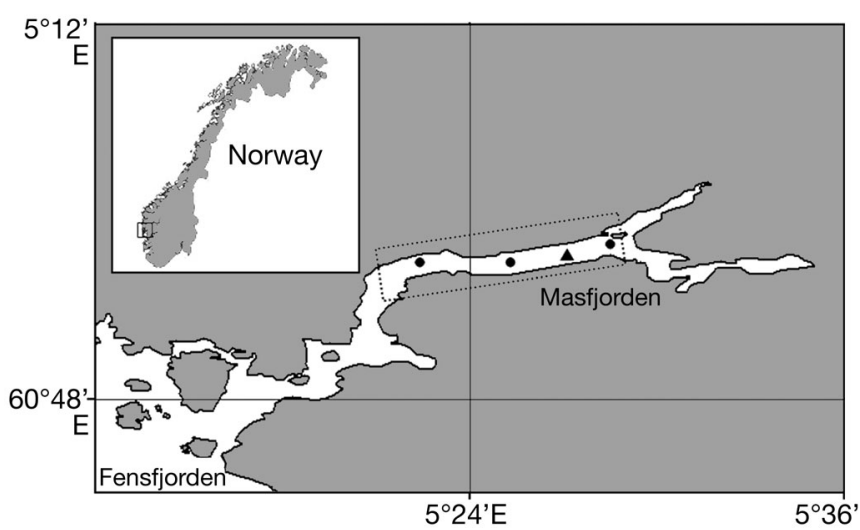

Fig. 1. Masfjorden on the west coast of Norway, showing the position of the $38 \mathrm{kHz}$ transducer ( $\mathbf{\Delta})$ at approximately $390 \mathrm{~m}$ depth, and oceanographic stations (๑). Trawl sampling of the mesopelagic community (see Tables 1 \& 2) was done within the dotted rectangle

\section{Field campaigns}

The continuous acoustic measurements were accompanied by 2 field campaigns for sampling acoustic SLs and collecting environmental data. Acoustic target identification was done with trawling in close proximity of the echo sounder. During 1 to 4 November 2007, the RV 'Håkon Mosby' (University of Bergen, Institute of Marine Research) and 3 to 7 October 2008, the RV 'Trygve Braarud' (University of Oslo) collected depth- and time-stratified samples with pelagic trawls. The trawls were equipped with a remotely controlled multisampler codend (Engås et al. 1997), which permitted depth-stratified sampling in 3 time intervals. Trawling from RV 'Håkon Mosby' was done with a Harstad trawl and from RV 'Trygve Braarud' with a somewhat smaller young-fish trawl. Since the trawls could be opened and closed on demand from the vessel, contamination of the catch as a result of the net fishing while descending and ascending was eliminated, ensuring more representative samples from the targeted acoustic layer. Trawling speed varied between 2 and 3 knots, while trawl duration for each net varied between 5 and 15 min. Trawling depth was monitored by depth sensors (Scanmar) during sampling. Catches from the 3 codends were emptied into separate baskets, weighed and sorted according to species. Individual large fish were not included in the weight of the total catch. When possible, the standard length of approximately 100 Maurolicus muelleri was measured. Trawls were grouped into day- and nighttime trawls; in November 2007, the local time of sunrise and sunset was at 8:15 $\mathrm{h}$ and 16:30 $\mathrm{h}(7: 00 \mathrm{~h}$ and 15:30 $\mathrm{h}$ UTC) and in October 2008 at 08:00 $\mathrm{h}$ and 18:50 h (06:00 h and 17:00 $\mathrm{h}$ UTC). The trawl coverage during both periods was extensive $(n=61)$, and covered the entire water column between the surface and the bottom in both diel periods.

\section{Environmental data}

Salinity, temperature $\left({ }^{\circ} \mathrm{C}\right)$ and dissolved oxygen $\left(\mathrm{ml} \mathrm{l}^{-1}\right)$ were measured during the field campaigns using a Seabird 911 CTD in November 2007 and a Falmouth Scientific CTD in October 2008. Photosynthetically active radiation (PAR) at 400 to $700 \mathrm{~nm}$ was recorded between January and October 2008 with a calibrated LI-190 quantum sensor (LI-COR Biosciences) and logged on an LI-1400 data logger (LICOR Biosciences). Surface irradiance was measured every $30 \mathrm{~s}$ and averaged over $15 \mathrm{~min}$, and average 
monthly surface irradiance was calculated from PAR measurements at 13:00 h (12:00 h UTC).

\section{RESULTS}

\section{Environment}

Temperature, salinity and oxygen plots from 2007 and 2008 are shown in Fig. 2. In both years, temperature $\left(8.6^{\circ} \mathrm{C}\right)$ and salinity (34.9) below $90 \mathrm{~m}$ depth were similar and showed little variation by depth. Above $80 \mathrm{~m}$ depth, temperature and salinity were less homogenous. In November 2007, temperature in the upper $60 \mathrm{~m}$ varied marginally $\left(10.4-11.3^{\circ} \mathrm{C}\right)$, while over the same depth range in October 2008 it decreased gradually from 14 to $8.5^{\circ} \mathrm{C}$. Similarly, salinity in 2007 varied little above the halocline at $70 \mathrm{~m}$ depth (32 to 33), while in 2008 it increased steadily from 31 to 34.9 at $80 \mathrm{~m}$. Oxygen concentrations at the surface (5-5.5 $\mathrm{ml} \mathrm{l}^{-1}$ ) decreased to 3.5-4 $\mathrm{ml} \mathrm{l}^{-1}$ and $2.5-3.5 \mathrm{ml}$ $\mathrm{l}^{-1}$ below $100 \mathrm{~m}$ in 2007 and 2008, respectively.

\section{Trawl sampling and acoustics during field campaigns}

The multisampler generally performed satisfactorily during both field campaigns, and we believe that the composition of acoustic targets (SLs) was adequately identified with the pelagic trawls. In both years, trawl catches included the most common and previously reported mesopelagic species (Table 1), including Maurolicus muelleri, glacier lanternfish Benthosema glaciale, northern krill Meganyctiphanes norvegica, shrimp Sergestes arcticus and glass shrimp Pasiphaea multidendata. During the 2 field campaigns, 3 SLs (2 SSLs at 50-75 m and the DSL at 115-175 m) were present in the daytime in November 2007 (see Fig. 6), while 3 SLs (postlarvae at 70-90 m, SSL at 110-125 $\mathrm{m}$ and DSL at 155-215 m) were observed in October 2008 (see Fig. 6). In the following section, trawl sampling data are cross referenced with these SLs and their corresponding depth intervals.

\section{7 field campaign}

Maurolicus muelleri dominated the species composition of SLs above $200 \mathrm{~m}$ depth, irrespective of diel period with catch rates of $M$. muelleri in the upper $200 \mathrm{~m}$ higher than for any other mesopelagic species (Table 1). During the trawl sampling campaign in November 2007, daytime catches at 100 to $150 \mathrm{~m}$ (corresponding to DSL depth) were dominated by large ( 40 mm) M. muelleri (Figs. 3 \& 4). At 70 m (corresponding with the lower SL of the 2 SSLs visible in Fig. 2), catches were dominated by $M$. muelleri (Table 1, Fig. 3), but were smaller than deeper cat-

Time (h), oxygen $\left(\mathrm{ml} \mathrm{l}^{-1}\right)$, temperature $\left({ }^{\circ} \mathrm{C}\right)$

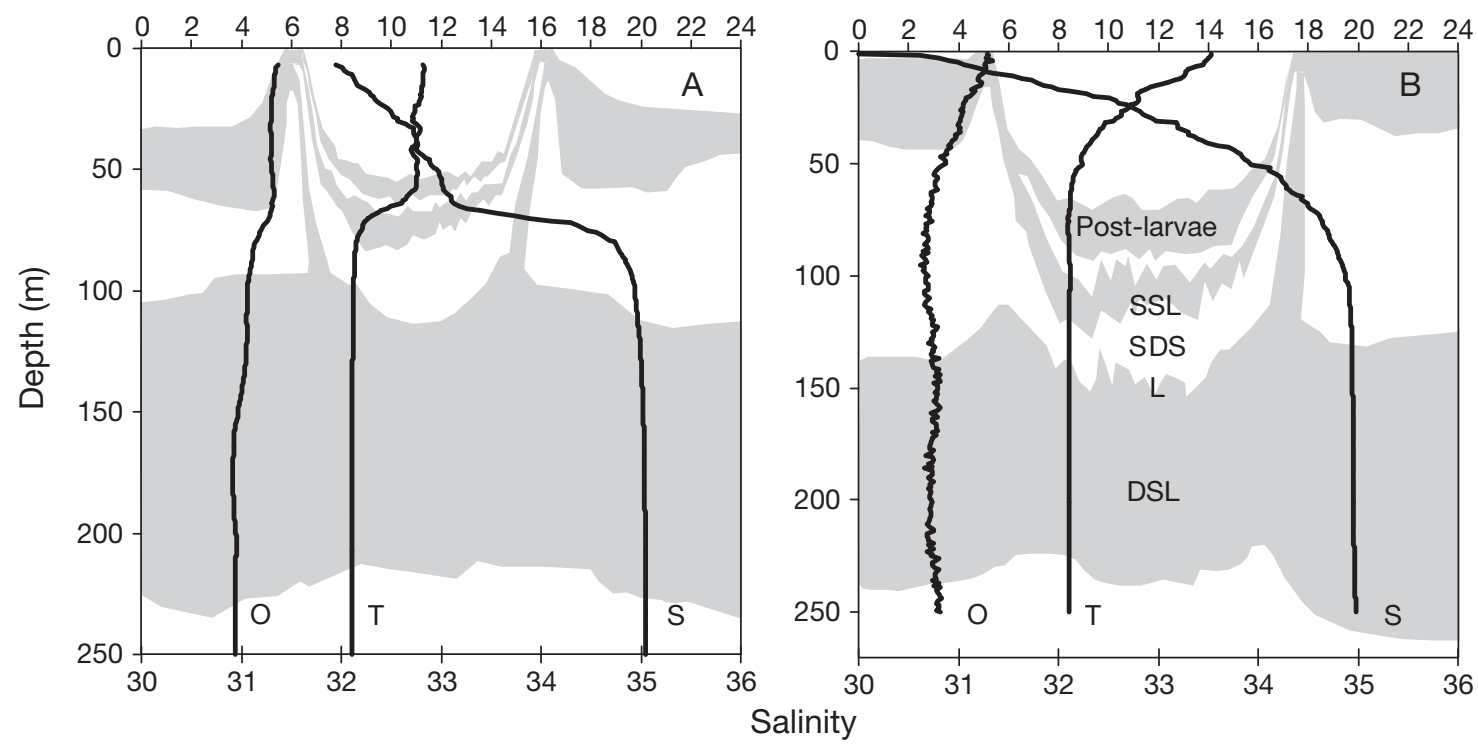

Fig. 2. Oceanographic conditions in Masfjorden near the site of the transducer in (a) November 2007 and (b) October 2008. Solid black lines show temperature (T), salinity $(\mathrm{S})$ and oxygen profiles $(\mathrm{O})$. Shaded areas depict the night- and daytime distribution of deep (DSL) and shallow scattering layers (SSL) composed of Maurolicus muelleri. In October 2008, the shallowest scattering layer was composed of pearlside post-larvae 
Table 1. Hourly catch rates $\left(\mathrm{kg} \mathrm{h}^{-1}\right)$ and numbers (no. $\mathrm{h}^{-1}$ ) of mesopelagic nekton caught in pelagic Harstad trawls in (A) November 2007 and (B) October 2008. Time is given as UTC (local time -1) and indicates when fishing started. N and D refer to night and day, while fishing depth was monitored with a depth sensor on the head line. Mm: Maurolicus muelleri, Bg: Benthosema glaciale, Mn: Meganyctiphanes norvegica, Sa: Sergestes arcticus, Pm: Pasiphaea multidendata

\begin{tabular}{|c|c|c|c|c|c|c|c|c|c|c|c|c|c|c|}
\hline \multirow[t]{2}{*}{ Date } & \multirow[t]{2}{*}{ Trawl } & \multirow[t]{2}{*}{ Time } & \multirow{2}{*}{$\begin{array}{c}\text { Fishing } \\
\text { depth }(\mathrm{m})\end{array}$} & \multirow{2}{*}{$\begin{array}{c}\text { Total catch } \\
(\mathrm{kg})\end{array}$} & \multicolumn{2}{|c|}{$-\mathrm{Mm}-$} & \multicolumn{2}{|c|}{$-\mathrm{Bg}-$} & \multicolumn{2}{|c|}{$-\mathrm{Mn}-$} & \multicolumn{2}{|c|}{$-\mathrm{Sa}-$} & \multicolumn{2}{|c|}{$-\mathrm{Pm}$} \\
\hline & & & & & $\mathrm{kg}$ & no. & $\mathrm{kg}$ & no. & $\mathrm{kg}$ & no. & $\mathrm{kg}$ & no. & $\mathrm{kg}$ & no. \\
\hline \multicolumn{15}{|c|}{ A. 2007} \\
\hline \multirow[t]{18}{*}{$2 \mathrm{Nov}$} & 1 & 00:28 (N) & 34 & 0.26 & 0.06 & 191 & 0.12 & 65 & 0.05 & 131 & & & 0.03 & 22 \\
\hline & 2 & 00:39 (N) & 38 & 0.33 & 0.01 & 54 & 0.14 & 78 & 0.05 & 126 & 0.03 & 60 & 0.10 & 72 \\
\hline & 3 & 00:49 (N) & 42 & 0.05 & 0.02 & 48 & & & & & 0.03 & 18 & & \\
\hline & 4 & 01:54 (N) & 40 & 0.56 & & & 0.04 & 18 & 0.02 & 42 & & & 0.50 & 306 \\
\hline & 5 & 02:05 (N) & 71 & 1.43 & 0.09 & 120 & 0.09 & 42 & & & & & 1.25 & 648 \\
\hline & 6 & 02:15 (N) & 77 & 0.71 & 0.04 & 65 & 0.02 & 16 & 0.00 & 5 & & & 0.65 & 365 \\
\hline & 7 & 03:19 (N) & 162 & 1.36 & 0.56 & 762 & 0.08 & 42 & 0.02 & 42 & 0.01 & 6 & 0.69 & 354 \\
\hline & 8 & 03:32 (N) & 155 & 1.96 & 1.66 & 2220 & 0.17 & 78 & 0.02 & 48 & 0.02 & 18 & 0.09 & 54 \\
\hline & 9 & 03:42 (N) & 156 & 2.1 & 1.20 & 1696 & 0.27 & 136 & 0.02 & 33 & 0.04 & 38 & 0.57 & 262 \\
\hline & 10 & 10:39 (D) & 70 & 0.07 & 0.07 & 404 & & & & & & & & \\
\hline & 11 & 10:50 (D) & 75 & 0.75 & 0.75 & 4385 & & & & & & & & \\
\hline & 12 & 11:00 (D) & 76 & 1.12 & 1.06 & 6294 & & & 0.00 & 6 & & & 0.06 & 6 \\
\hline & 13 & 12:13 (D) & 135 & 28.6 & 28.55 & 44275 & & & 0.05 & 164 & & & & \\
\hline & 14 & 12:24 (D) & 135 & 36.36 & 36.25 & 51987 & & & 0.11 & 295 & & & & \\
\hline & 15 & 12:35 (D) & 136 & 18.31 & 18.26 & 23553 & & & 0.05 & 125 & & & & \\
\hline & 16 & 13:54 (D) & 272 & 1.54 & 0.05 & 48 & 1.05 & 384 & 0.00 & 6 & 0.38 & 252 & 0.06 & 24 \\
\hline & 17 & 14:05 (D) & 276 & 4.3 & 0.14 & 144 & 3.26 & 606 & 0.00 & 6 & 0.74 & 498 & 0.16 & 48 \\
\hline & 18 & 14:16 (D) & 277 & 1.82 & 0.12 & 144 & 1.30 & 492 & 0.00 & 12 & 0.36 & 276 & 0.04 & 24 \\
\hline \multirow[t]{6}{*}{$3 \mathrm{Nov}$} & 25 & 01:35 (N) & 276 & 2.14 & 0.01 & 12 & 1.79 & 636 & & & 0.34 & 264 & & \\
\hline & 26 & 01:41 (N) & 273 & 6.34 & 0.02 & 30 & 5.48 & 2040 & 0.04 & 105 & 0.79 & 630 & 0.01 & 15 \\
\hline & 27 & 01:43 (N) & 269 & 3.37 & 0.08 & 105 & 2.83 & 1080 & & & 0.38 & 315 & 0.08 & 15 \\
\hline & 28 & 03:36 (N) & 35 & 1.69 & 0.27 & 588 & 0.50 & 210 & 0.52 & 1446 & 0.08 & 60 & 0.32 & 192 \\
\hline & 29 & 03:47 (N) & 35 & 1.28 & 0.42 & 924 & 0.06 & 24 & 0.30 & 1092 & 0.04 & 96 & 0.46 & 282 \\
\hline & 30 & 03:57 (N) & 34 & 1.59 & 0.38 & 1176 & 0.23 & 102 & 0.43 & 1032 & 0.13 & 204 & 0.42 & 264 \\
\hline $4 \mathrm{Nov}$ & 34 & $04: 22(\mathrm{~N})$ & 40 & 1.88 & 0.98 & 2340 & & & 0.22 & 630 & 0.04 & 132 & 0.64 & 348 \\
\hline \multicolumn{15}{|c|}{ B. 2008} \\
\hline 3 Oct & 1 & 13:25 (D) & 218 & 9.8 & 6.88 & 6367 & 2.48 & 1987 & 0.24 & 609 & 0.20 & 775 & & \\
\hline & 2 & 13:35 (D) & 217 & 13.23 & 9.12 & 8132 & 3.47 & 2776 & 0.27 & 676 & 0.37 & 1425 & & \\
\hline & 3 & 13:51 (D) & 210 & 13.93 & 11.61 & 10996 & 1.35 & 1091 & 0.36 & 890 & 0.61 & 2338 & & \\
\hline 4 Oct & 4 & 09:54 (D) & 120 & 4.93 & 4.93 & 41372 & & & & & & & & \\
\hline & 5 & 10:05 (D) & 122 & 6.15 & 6.15 & 44565 & & & & & & & & \\
\hline & 6 & 10:16 (D) & 120 & 9.26 & 9.26 & 60035 & & & & & & & & \\
\hline & 7 & 11:26 (D) & 79 & & & & & & & & & & & \\
\hline & 8 & 11:36 (D) & 78 & Larvae & & & & & & & & & & \\
\hline & 9 & 11:48 (D) & 78 & & & & & & & & & & & \\
\hline & 10 & 13:09 (D) & 200 & 18.69 & 17.86 & 13754 & 0.40 & 1218 & 0.28 & 750 & 0.15 & 516 & & \\
\hline & 11 & $13: 20$ (D) & 195 & 20.18 & 19.72 & 21503 & 0.09 & 436 & 0.34 & 845 & 0.03 & 169 & & \\
\hline & 12 & 13:31 (D) & 196 & 37.89 & 37.00 & 34904 & 0.19 & 960 & 0.53 & 1224 & 0.17 & 573 & & \\
\hline & 13 & $14: 38$ (D) & 175 & 39.44 & 39.04 & 36186 & & 42 & 0.40 & 1080 & 0.00 & 18 & & \\
\hline & 14 & $14: 49$ (D) & 162 & 19.21 & 18.76 & 20886 & & 30 & 0.45 & 1164 & 0.00 & 24 & & \\
\hline & 15 & 15:00 (D) & 144 & 3.78 & 3.55 & 3717 & & & 0.23 & 852 & 0.00 & 0 & & \\
\hline 5 Oct & 16 & 10:46 (D & 266 & 3.12 & 0.31 & 320 & 2.34 & 700 & 0.02 & 40 & 0.45 & 510 & & \\
\hline & 17 & 10:59 (D) & 265 & 5.56 & 0.04 & 42 & 3.79 & 1260 & 0.02 & 48 & 1.70 & 1778 & 0.01 & 6 \\
\hline & 18 & 11:11 (D) & 273 & 5.29 & 0.01 & 12 & 4.52 & 1386 & 0.02 & 48 & 0.74 & 684 & & \\
\hline & 19 & 18:12 (D) & 222 & 6.32 & 2.12 & 2005 & 3.13 & 1530 & 0.03 & 75 & 0.99 & 860 & 0.05 & 20 \\
\hline & 20 & $18: 51(\mathrm{~N})$ & 220 & 2.76 & 1.45 & 1506 & 0.69 & 504 & 0.01 & 24 & 0.60 & 384 & 0.01 & 6 \\
\hline & 21 & 20:54 (N) & 220 & 1.8 & 0.56 & 504 & 0.34 & 180 & 0.01 & 30 & 0.89 & 600 & 0.00 & 6 \\
\hline 7 Oct & 22 & $17: 22(\mathrm{~N})$ & 14 & 1.85 & 1.64 & 2280 & & & 0.21 & 2388 & & & & \\
\hline & 23 & $17: 42(\mathrm{~N})$ & 14 & 11.58 & 10.95 & 64968 & 0.04 & 240 & 0.50 & 2808 & 0.09 & 580 & & \\
\hline & 24 & $18: 03(\mathrm{~N})$ & 14 & 7.02 & 3.44 & 15020 & 0.39 & 2416 & 1.55 & 4932 & 1.64 & 5456 & & \\
\hline & 25 & $18: 54(\mathrm{~N})$ & 15 & 10.63 & 5.84 & 41360 & 0.29 & 880 & 3.54 & 10080 & 0.74 & 2080 & 0.22 & 80 \\
\hline & 26 & $19: 16(\mathrm{~N})$ & 26 & 11.86 & 8.41 & 58368 & 0.22 & 395 & 2.45 & 6775 & 0.57 & 1777 & 0.21 & 132 \\
\hline & 27 & 19:44 (N) & 27 & 16.86 & 11.19 & 74597 & 0.06 & 566 & 3.94 & 11271 & 1.05 & 3240 & 0.62 & 566 \\
\hline
\end{tabular}




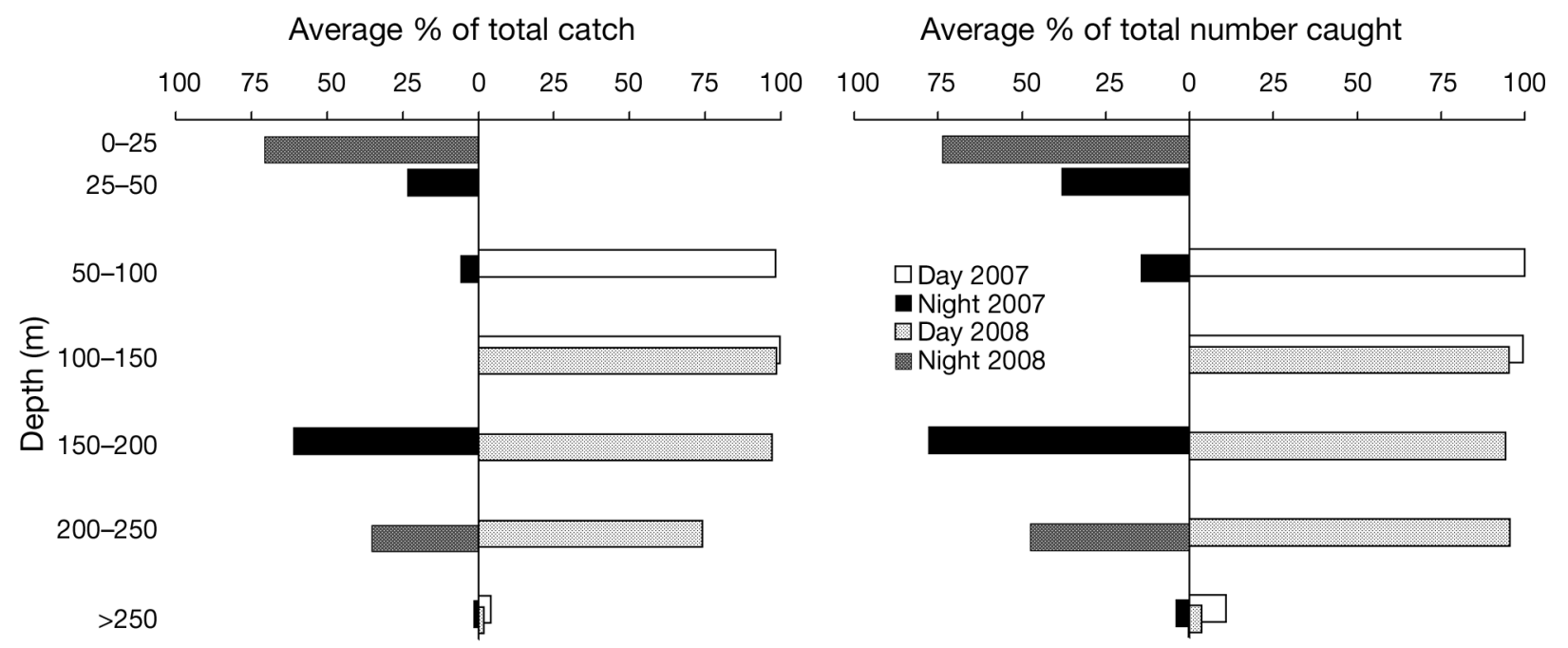

Fig. 3. Maurolicus muelleri. Average percentage of the total catch in weight (left) and number (right) per depth range
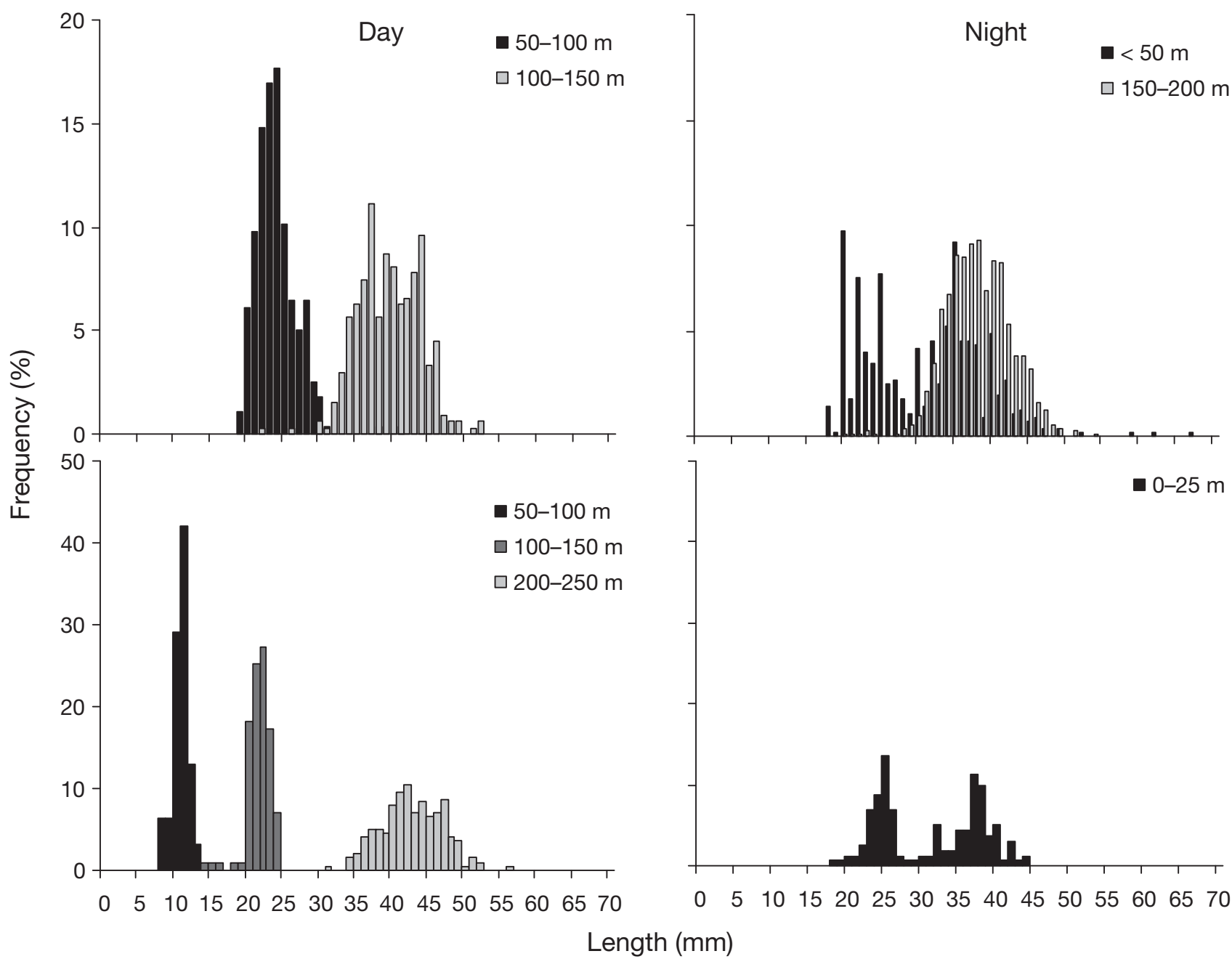

Fig. 4. Maurolicus muelleri. Length frequency distributions during the day (left) and at night (right) at different depth ranges in 2007 (top) and 2008 (bottom) 
ches and consisted of smaller individuals ( 24 mm, Fig. 4). During the night, $M$. muelleri were caught in the upper $50 \mathrm{~m}$ and varied in size (20-45 mm, Fig. 4). Numbers were low, but $M$. muelleri were still more abundant than any other identified mesopelagic species (Table 1). Krill (18\% of weight and $19 \%$ of number) and glass shrimp (30\% of weight and $38 \%$ of number) were also caught frequently at the surface at night. Nighttime catch rates of large $M$. muelleri (38 $\mathrm{mm}$ ) at 150-165 $\mathrm{m}$ were lower than daytime catch rates at similar depths (Table 1 ).

\section{8 field campaign}

Similar to 2007, Maurolicus muelleri dominated the species composition of SLs above $250 \mathrm{~m}$ depth, irrespective of diel period (Table 1). The SL at 70 to $90 \mathrm{~m}$ in October 2008 (Fig. 2) likely consisted of M. muelleri post-larvae ( $11 \mathrm{~mm}$, Fig. 4). This was suggested from a tow at approximately $80 \mathrm{~m}$ depth that only contained many small and transparent M. muelleri post-larvae entangled in the netting in front of the multisampler unit. Trawls at $120 \mathrm{~m}$ (corresponding to SSL depth in Fig. 2) and 190 to $220 \mathrm{~m}$ (corresponding to DSL depth in Fig. 2) caught juvenile $(21 \mathrm{~mm})$ and adult (43 mm) M. muelleri, respectively (Fig. 4), and contained $>95 \%$ M. muelleri in terms of weight and numbers (Fig. 3). Juvenile and adult $M$. muelleri were abundant in night trawls at 0 to $25 \mathrm{~m}$ (Table 1 , Fig. 4) and contained $74 \%$ and $71 \%$ M. muelleri in terms of number and weight, respectively (Fig. 3). Besides M. muelleri, krill was the only other mesopelagic species caught frequently in the upper $25 \mathrm{~m}$ during nighttime $(19 \%$ of the catch in terms of weight and number, Table 1). Below $250 \mathrm{~m}$, catches were generally dominated by the glacier lanternfish and shrimp, regardless of diel period (Table 1).

\section{Behaviour of the shallow scattering layer (SSL)}

The SSL ascribed to juvenile Maurolicus muelleri was present between November and May (Fig. 5). Throughout this period, fish from the SSL performed normal DVM and displayed midnight sinking between dusk and dawn from 2 November 2007 until 24 April 2008 (visible on 110 echograms; Fig. 5). The depth to which fish descended when displaying midnight sinking varied between months, showing a trend of increasing depth until January and then a reverse trend until the end of April (Fig. 5). Interrupted (arrested) migration behaviour, where groups of fish suspended their ascent at dusk and which was observed from 10 January until 9 April 2008 (visible on 42 out of 52 echograms), increased in intensity throughout February and became less pronounced towards the beginning of April (Fig. 5). Fish that displayed this behaviour broke off their ascent at random depths and subsequently descended to deeper depths, spreading over a wide depth range and creating a near continuous layer between 50 and $150 \mathrm{~m}$ at nighttime (Fig. 5). From March until May, SLs increasingly overlapped during the day, while fish from migrating SLs seemingly spread out at different depths during nighttime (Fig. 5). Prior to the firm establishment of the SSL in October/November, a shallower layer, likely $M$. muelleri post-larvae, was variably present from July/August until October (Fig. 5).

Behaviour of the deep scattering layer (DSL)

In both years, the DSL ascribed to adult Maurolicus muelleri displayed normal DVM behaviour during spring and summer months, ascending from $~ 150$ to $200 \mathrm{~m}$ during the day to the surface in the evening and returning to depth in the morning (Fig. 5). The DVM behaviour of the DSL changed in the course of September in both years, with an increasing number of fish suspending their dusk migration. By the beginning of October, most fish from the DSL stayed at approximately daytime depths after dusk in both years (Fig. 5). Yet, in 2007, the majority of the population ascended during the latter part of the night, starting the ascent already around midnight, with the fish spending the dawn period in surface waters (Fig. 5). Early morning ascents were visible from 17 September until 5 November 2007 (visible on 25 out of 29 echograms). This type of behaviour was not recorded in autumn 2008. Also, among the relatively low number of fish that ascended into shallower waters at dusk in October 2007, many returned all the way to their daytime depth after a short stay near the surface. In October 2008, on the other hand, the small proportion of fish that undertook DVM remained at the surface after dusk and did not descend to deeper depths until the morning (Fig. 5).

At the beginning of November, only a hazy (by seemingly few individuals) ascent from and descent to the daytime DSL depth was observed. At this stage, the majority of fish remained at approximately the same depth during day- and nighttime, dispersing in a broad continuous layer (Fig. 5). Between late November and 20 March 2008, DSL fish ceased to undertake normal DVM to upper waters entirely (vis- 

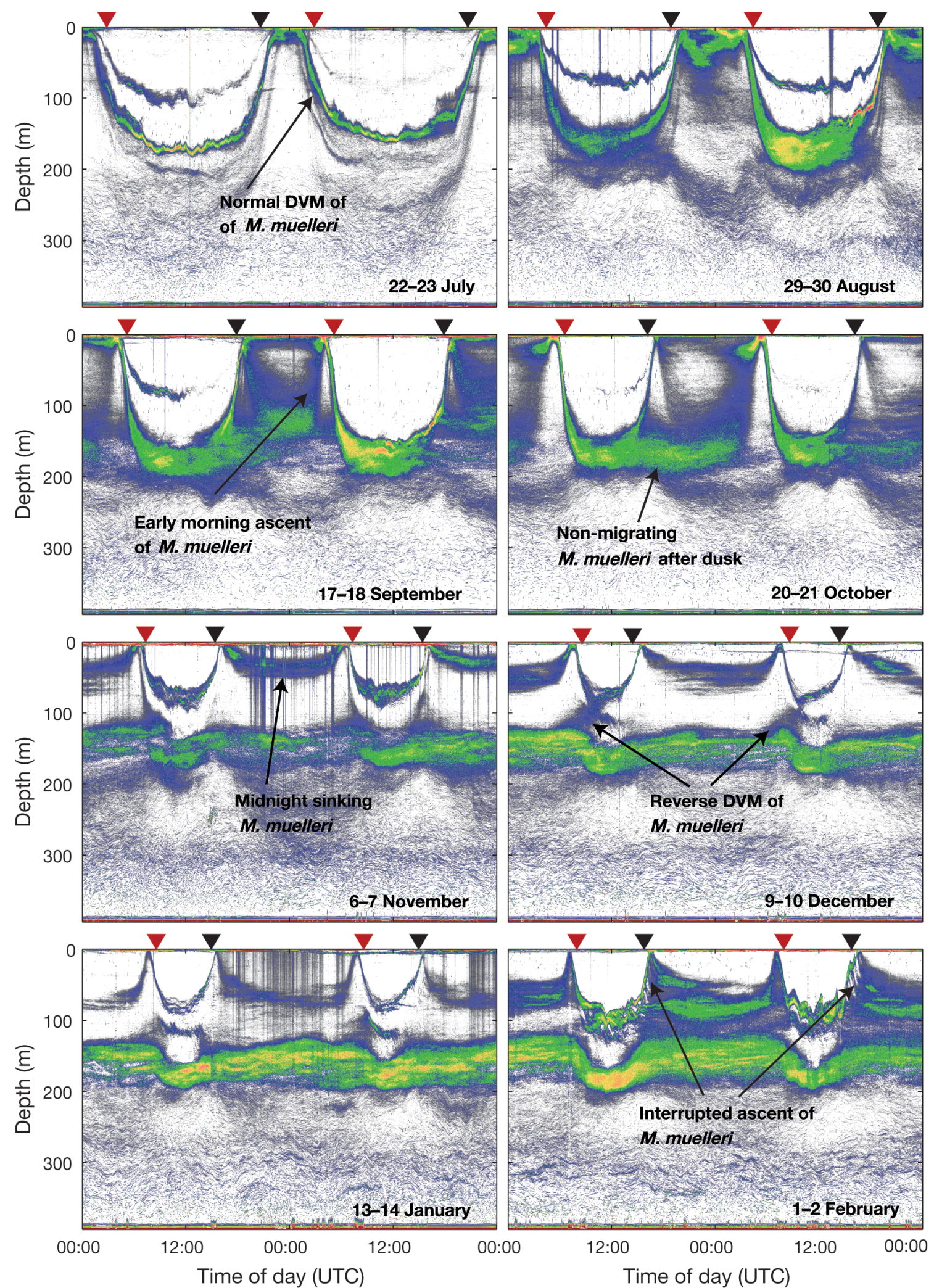

Fig. 5. Daily echograms from selected consecutive days in 2007 (July to December) and 2008 (January to October; continued on next page). Behaviours of Maurolicus muelleri and the composition of the shallowest scattering layer in October 2008 are indicated. Red arrowheads: time of sunrise. Black arrowheads: time of sunset. DVM: diel vertical migration 

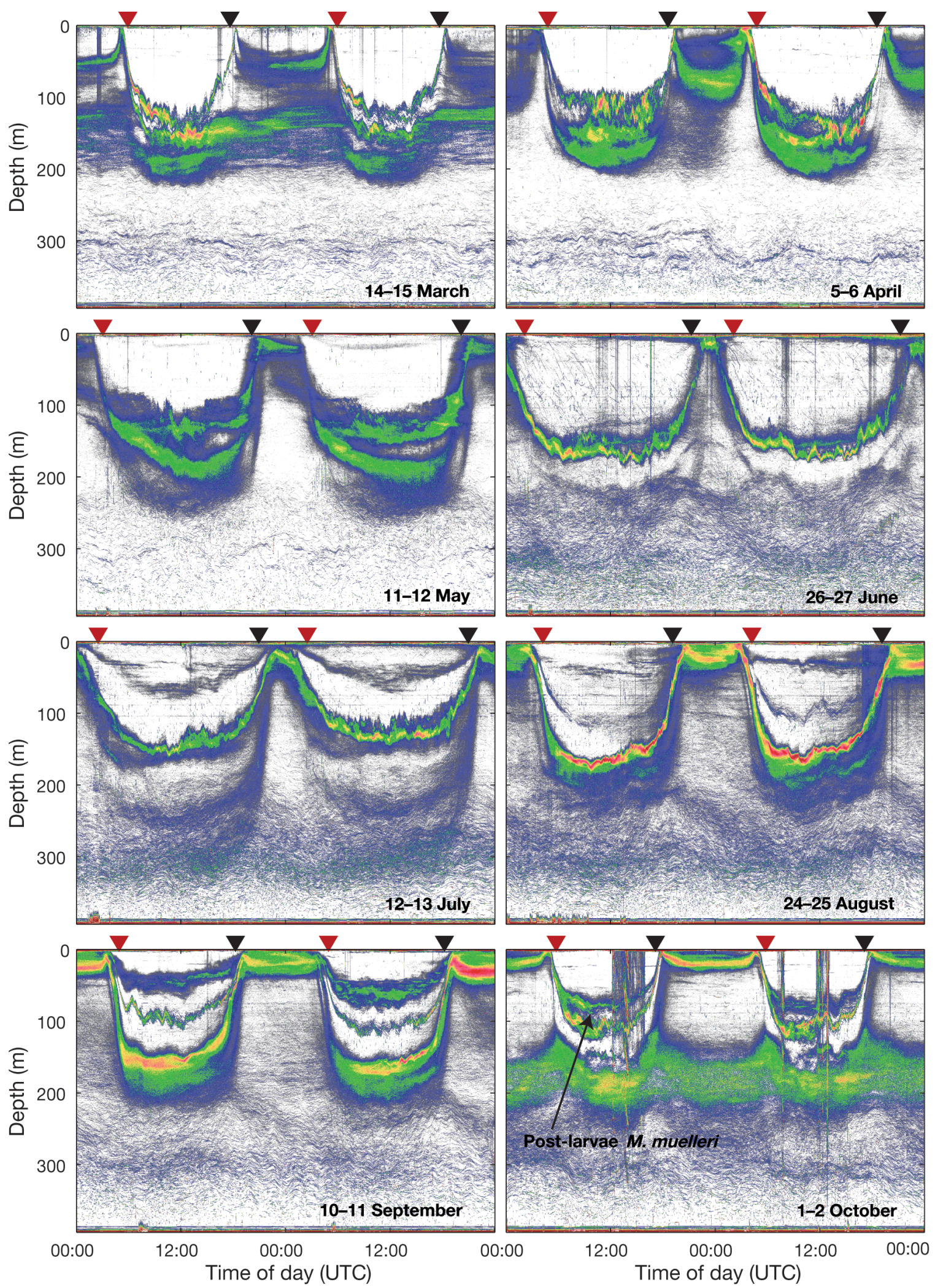

Fig. 5 (continued) 
ible in 77 echograms), but the depth during the day was for the majority of targets slightly deeper than at night. However, from 26 November 2007 until 30 January 2008 (visible on 41 echograms), a proportion of fish migrated upwards $(20-50 \mathrm{~m})$ in the daytime and were clearly separated from the deeper part of the DSL, which simultaneously moved slightly deeper (Fig. 5). Around mid-day, the 'reverse DVM' fish descended and merged again with the slightly ascending deeper layer.

Within a $2 \mathrm{wk}$ period, between the end of March and the beginning of April, the behaviour of the DSL changed, with the large majority of DSL fish performing a complete DVM cycle, migrating to the surface at dusk and back to deeper waters at dawn (Fig. 5). During the spring months, the nature of SLs made it difficult to identify individual layers. However, this does not affect the conclusion of changed behaviour for the DSL, as all layers carried out normal DVM. It seemed that the DSL and SSL had merged into a single layer by June (Fig. 5).

The upper and lower boundary as well as vertical extent of the DSL varied within and between months, yet depth of the upper limit was fairly constant (Fig. 6). Average monthly mid-day depth of the DSL's upper depth limit was approximately 140 to $150 \mathrm{~m}$, with the highest variation in depth in June (Fig. 6). The lower border displayed more pronounced seasonal variation. It was shallowest $(\sim 180 \mathrm{~m})$ in June and July and deepest in October 2008 (near $250 \mathrm{~m}$ ). The vertical extent of the DSL was narrowest (14-28 m) during spring and summer months compared to autumn and winter months (47-62 m). The upper border of the DSL appeared to be unrelated to the seasonal changes in surface light (Fig. 6). The lower border of the DSL had its shallowest distribution when the average surface irradiance at midday was highest, i.e. 10 to 15 times higher than in winter months (Fig. 6)

\section{Timing of SL descent and ascent}

The relationship between seasonally changing daylight length and the timing of descent from and arrival at the surface is shown in Fig. 7. Regardless of season and ontogeny, SLs descended from the surface shortly before sunrise and arrived at the surface shortly after sunrise. The time interval showed some seasonal variation, and increased towards summer (Fig. 7). On several of the light summer nights in June and July 2008, Maurolicus muelleri seemingly did not migrate into the upper $5 \mathrm{~m}$ of the surface, which explains the lack of data points for those days in Fig. 7 .
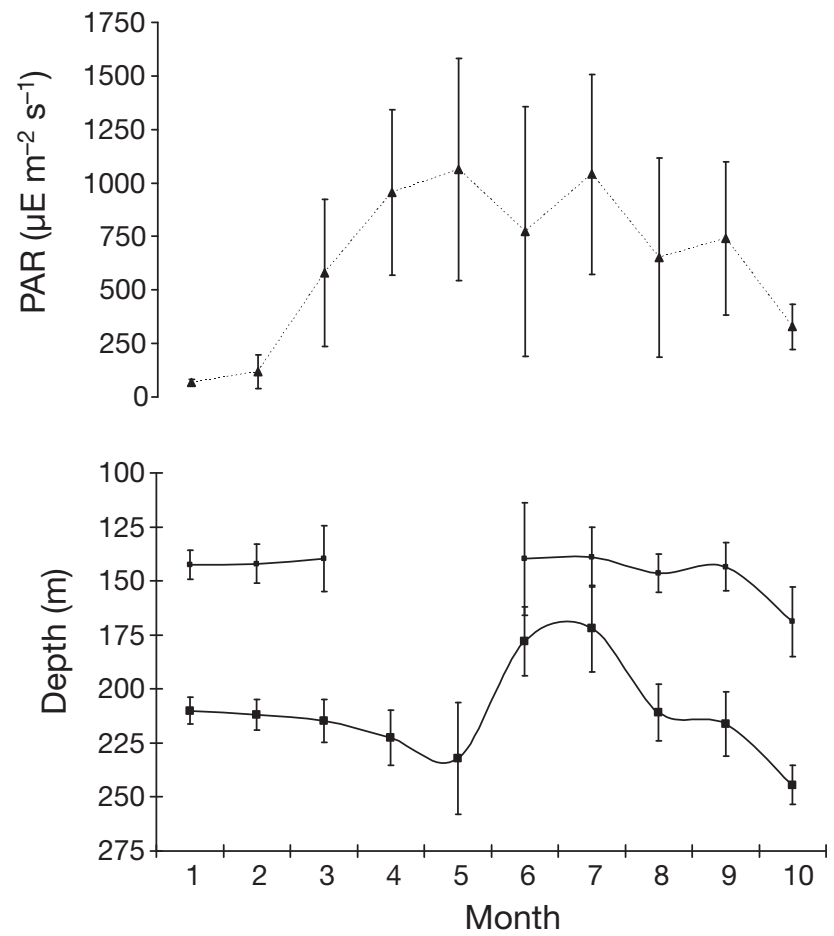

Fig. 6. Average monthly upper (small squares) and lower (i.e. deeper; large squares) depth limits of the deep scattering layer (DSL) and corresponding surface irradiance (triangles) from January to October 2008. Error bars indicate 1 SD of the average monthly surface irradiance and depth limits. From March to May, the upper depth limit of the DSL could not be determined due to overlap with shallower scattering layers at noon

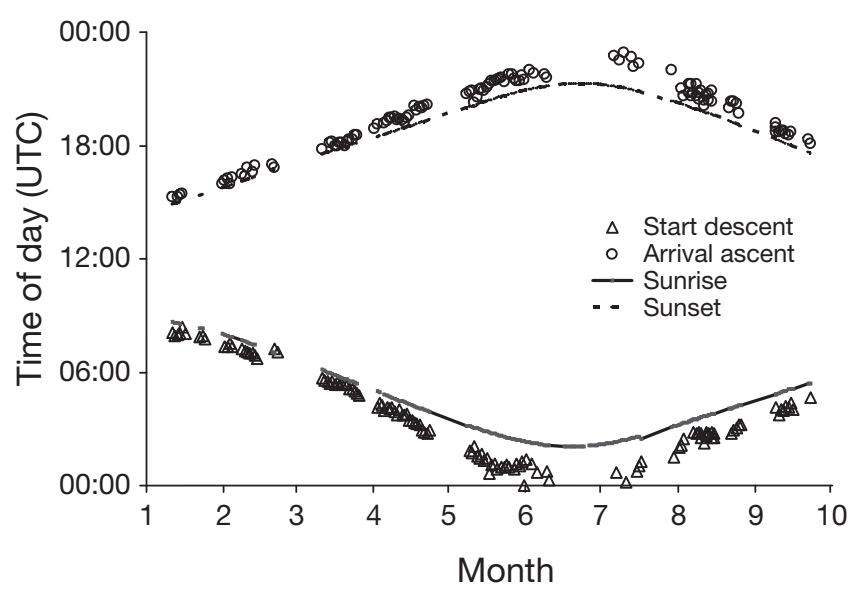

Fig. 7. Maurolicus muelleri. Times of departure from (beginning of descent) and arrival at (end of ascent) the surface of $M$. muelleri scattering layers based on acoustic echograms from the period January to September 2008. Sunrise (between 02:00 and 09:00) and sunset (between 15:00 and 21:00) at Masfjorden are indicated for the same period, for every instance for which data were available 


\section{DISCUSSION}

The present study describes flexible DVM patterns of Maurolicus muelleri that change throughout the year and also between years. The continuous acoustic data through 15 mo revealed known patterns like normal DVM and no DVM, but also novel migration patterns comprising interrupted ascents in the afternoon, reverse DVM with ascent at day and migrations restricted to early morning ascents.

\section{Trawl sampling and acoustics}

We are confident that the acoustic backscattering from the SSL and DSL primarily represented Maurolicus muelleri. This was suggested by the trawl catches during the field campaigns and is also in full concordance with sampling during a great number of earlier studies from different times of the year, identifying the SSL as juvenile $M$. muelleri and the DSL as adult M. muelleri (Kaartvedt et al. 1988, 2008, Giske et al. 1990, Baliño \& Aksnes 1993, Rasmussen \& Giske 1994, Bjelland 1995, Goodson et al. 1995, Bagøien et al. 2001). In addition, we for the first time sampled post-larvae $M$. muelleri in autumn, which likely constituted the shallowest SL at that time when 3 separate daytime SLs were observed.

Acoustic properties also help identify the layers. Maurolicus muelleri has a gas-filled swim bladder and as a result, an order of magnitude higher target strength than invertebrate targets like krill and shrimps (Torgersen \& Kaartvedt 2001, Klevjer \& Kaartvedt 2006). Kaartvedt et al. (2008) furthermore recorded the same SLs at $18 \mathrm{kHz}$, and the nonresonating invertebrates would not contribute substantially at this frequency (Love et al. 2004). The main uncertainty in target identification relates to the lower edge of the DSL. The abundance of the mesopelagic lanternfish Benthosema glaciale increased below 200 m, as outlined by Kaartvedt et al. (2009) from this same study, and which was also observed in previous studies (Kaartvedt et al. 1988, Bagøien et al. 2001). Since the lower border of the DSL was often not clearly defined, with the exception of June and July, it is likely that $B$. glaciale to some extent contributed with backscatter in its lower edge at about $200 \mathrm{~m}$ and was the dominant target below (Kaartvedt et al. 2009).

\section{Relation to temperature}

Temperature gradients can modify the vertical depth distribution of zooplankton and fish (South- ward \& Barrett 1983, Perry \& Neilson 1988, Neilson $\&$ Perry 1990). Zooplankton may often concentrate at the depth range of the thermocline, whereas the mean daytime depth of age-0 (post-larvae) gadoids seemingly corresponded with the steepest change in temperature (Southward \& Barrett 1983, Perry \& Neilson 1988). During our field campaigns, the thermocline was much stronger in 2007 than in 2008. Yet, in both years the daytime depth selection of the SSLs suggests that differences in temperature gradients did not strongly influence the vertical distribution of either juvenile or post-larval Maurolicus muelleri. With the exception of the daytime SSL in November 2007, the distribution of juveniles and post-larvae did not seem to correspond with the thermocline generally located at approximately sill depth between 70 and $90 \mathrm{~m}$ (Kaartvedt et al. 1988, Aksnes et al. 1989, Baliño \& Aksnes 1993, Bagøien et al. 2001). The temperature in Masfjorden is nearly constant below sill depth, such that the temperature had little explanatory power for daytime distributions of the DSL.

Some part of the population migrated to the surface throughout the year, so neither warm nor cold water seemed to represent a physical barrier for ascent. However, selection of nighttime depth by juvenile Maurolicus muelleri has previously been related to temperature (Giske \& Aksnes 1992), as it has for other species of fish (Levy 1990b). Juvenile M. muelleri displayed nighttime descents (nocturnal or midnight sinking) between October and April. Giske et al. (1990) observed that the nighttime distribution of juveniles subsequent to midnight sinking in winter corresponded with the temperature maximum. Distributing at higher temperatures might result in increased fitness (growth) due to higher digestion rates (Giske \& Aksnes 1992). However, during the sampling campaign in November 2007, the temperature was relatively constant in the upper $60 \mathrm{~m}$, while over the same depth range, the temperature decreased in October 2008 (Fig. 2). Juvenile M. muelleri nevertheless performed midnight sinking, so that the temperature does not seem to be the primary factor for this behaviour. We rather suggest that midnight sinking took place to evade shallow foraging predators by migrating to deeper depths during periods when they do not feed themselves (Staby 2010). This does not negate that temperature can modify nocturnal distribution, and the acoustic records demonstrated a deepening nocturnal distribution of the SSL in winter (Fig. 5), which would be in accordance with an expected progressive cooling of the upper waters (e.g. Bagøien et al. 2001). 


\section{Relation to light}

Daytime depth distribution of SLs is related to surface light intensity (Baliño \& Aksnes 1993, Staby \& Aksnes 2011). Light is an important proximate factor in DVM (Neilson \& Perry 1990, Cohen \& Forward 2009), but light-dependent behaviour may be modified by the ontogeny and state of the migrating organism, as well as the presence and absence of prey and predators (Neilson \& Perry 1990, Ringelberg 1991). The timing of the departure from the surface at dawn and the arrival at the surface at dusk followed seasonal changes in the daylight duration (Fig. 7). Staby \& Aksnes (2011) showed that the vertical depth distribution of Maurolicus muelleri is the result of a vertical habitat selection that can be characterised by the preference of a restricted range of light intensities, irrespective of weather and season, and it seems likely that the timing of $M$. muelleri SLs is the result of the species following a preferred light level. However, the upper edge of the DSL remained virtually constant throughout the year. The average monthly surface irradiance was approximately 10 times higher in June than in January, yet the average upper edge of the DSL did not distribute deeper and the lower edge was shallower in June and July (Fig. 6). Water clarity will change throughout the year, which may augment or dampen the effect of variations in surface light, but would not likely cause a constant light regime at $\sim 150 \mathrm{~m}$ depth. Thus, the effect of light on the distribution of the DSL has to be modified by other factors, as referred to above.

\section{Behavioural variations}

Interrupted ascents

Interrupted migrations in which groups of organisms left the SSL and returned to depth in the course of the afternoon ascent were recorded from January to mid-March. Interrupted dusk migrations of entire Maurolicus muelleri SLs have been linked to high surface light intensity on bright summer nights (Kaartvedt et al. 1998). This explanation does not apply here, since, in contrast to summer nights, light intensities in winter months are below $0.0001 \mu \mathrm{E} \mathrm{m}^{-2} \mathrm{~s}^{-1}$ after twilight ends (A. Staby unpubl. data). It is also unlikely that this is affected by the lunar phase or nocturnal light, which can influence the nocturnal depth distribution of micronekton (Benoit-Bird et al. 2009). This behaviour occurred consistently through a period in winter, and the interrupted ascent was a within-population pattern with groups of fish leaving at different depths. One possible explanation is that this is related to feeding. Fish from the SSL consume copepods in winter months (Giske et al. 1990, Bagøien et al. 2001), and Calanus, the most abundant copepod prey for juvenile $M$. muelleri in Masfjorden (Bagøien et al. 2001), presumably ascend from overwintering depths in mid-February, with the ascent lasting several weeks (depending on the initial migration depth, Heath 1999). Possibly, juvenile $M$. muelleri may forage on seasonally ascending copepods while following a preferred light level during their ascent and return to depth according to their state of satiation.

Normal migration among adults

Adult Maurolicus muelleri performed DVM between April and September/October (Fig. 7), consistent with findings from earlier studies (Rasmussen \& Giske 1994, Bjelland 1995, Goodson et al. 1995). During this period, fish feed extensively on shallow distributed zooplankton during the crepuscular periods (Bjelland 1995, Rasmussen \& Giske 1994), investing energy in gonad development and build-up of energy (lipid) reserves before the onset of the next winter period (Falk-Petersen et al. 1986).

\section{Early morning vertical migrations}

From the latter half of September to the end of October 2007, a large proportion of adult Maurolicus muelleri did not migrate to the surface at dusk, but remained at depth during nighttime, only to migrate to be at the surface the following morning. This is to the best of our knowledge a novel observation. Previous studies have shown that planktonic organisms, which were in a better condition, e.g. had larger lipid reserves (Hays et al. 2001) or were well fed (Forward \& Hettler 1992), restrained from ascending at dusk, in contrast to organisms that were in worse condition or starved during daytime. A possible explanation for the general lack of an evening ascent might therefore be that non-migrators were in better condition and did not need to migrate to the surface at dusk to feed. Alternatively, non-migrating individuals might have foraged sufficiently on deep-living prey during the day to suppress a hunger sensation past dusk, restraining fish from migrating to surface waters to feed. According to this interpretation, food conditions at the daytime depth of $M$. muelleri may have been poorer in the subsequent autumn, when M. muelleri per- 
formed normal DVM in the evening. Results from plankton tows support this hypothesis. The concentrations of overwintering Calanus in midwaters are generally at a seasonal high in the autumn, and they occur in maximum abundance at depths inhabited by the DSL (Bagøien et al. 2001). Srisomwong (2009) found relatively high concentrations ( $>100$ inds. $\mathrm{m}^{-3}$ ) of copepods at 150 to $200 \mathrm{~m}$ depth in early November 2007, while numbers of deep-living copepods were about an order of magnitude lower in early October of the subsequent autumn (e.g. only 4 Calanus $\mathrm{m}^{-3}$, Dypvik 2010). As M. muelleri does not feed at night (Giske et al. 1990, Srisomwong 2009), hunger would motivate ascent in the morning, as long as there is sufficient food in the surface layer for taking the risk. Fish migrated to the surface within an approximately $3 \mathrm{~h}$ long window after midnight, reaching the surface well before sunrise. The early start of the morning ascent, long before any signs of dawn, suggests that it is triggered by either changes in state or endogenous rhythmicity rather than by changes in light conditions.

\section{Non-migrating individuals}

Between the end of November 2007 and mid-March 2008, Maurolicus muelleri from the DSL suspended their migration to the surface at dusk entirely. By remaining at depth, as opposed to performing DVM, $M$. muelleri may reduce predation risk during periods with scant surface concentrations of zooplankton. By avoiding shallow foraging predators (Staby 2010), they increase the likelihood of survival and thus future reproductive output during the next spawning season (Giske \& Aksnes 1992, Rosland \& Giske 1994, 1997). This change in behaviour implies that adult fish are able to survive at depth through feeding on deep distributed prey in daytime (Giske et al. 1990, Bagøien et al. 2001) and/or by using lipid reserves (Falk-Petersen et al. 1986, Hulley \& Prosch 1987). The proportion of overwintering adults feeding in daytime and the number of prey ingested (mainly overwintering copepods) are probably relatively low (Bagøien et al. 2001, Srisomwong 2009), with feeding rates at best sufficient to maintain zero growth (Giske \& Aksnes 1992, Rosland \& Giske 1997).

\section{Reverse DVM}

During the winter period without normal DVM, a proportion of individuals from the DSL displayed reverse DVM by moving approximately 20 to $30 \mathrm{~m}$ higher up in the water column before mid-daytime and down again after noon. This behaviour has not been described for Maurolicus muelleri before, and generally few studies have described reverse diel vertical migrations among fish (Levy 1990a, Neilson \& Perry 1990, Kaartvedt et al. 2009). While a short ascent into a brighter environment might increase the predation risk (Rosland \& Giske 1997, Staby 2010), i.e. the light intensity would increase by a factor of 7 to 20 when 20 to $30 \mathrm{~m}$ shallower (given a light extinction coefficient of $0.1 \mathrm{~m}^{-1}$ ), feeding conditions can be improved with enhanced visibility and higher encounter rates with deep distributed prey (Giske \& Aksnes 1992, Vogel \& Beauchamp 1999, Bagøien et al. 2001). Kaartvedt et al. (2009) suggested that deep distributed Benthosema glaciale displayed reverse DVM during daytime in order to improve light conditions for feeding on Calanus, which typically overwinter at 150 to $250 \mathrm{~m}$ (Giske et al.1990, Kaartvedt 1996, Bagøien et al. 2001). Reverse diel migrations of some M. muelleri may thus be the result of improved feeding on the upper fringe of the overwintering population of Calanus. It should be noted that during the same period, large fish seemingly performing normal DVM were observed between the reverse migrating fish and the deeper M. muelleri layer (Staby 2010), suggesting that reverse migrating fish may take greater risks associated with their feeding.

In summary, this study has unveiled more flexible DVM patterns of Maurolicus muelleri than previously reported. It underlines the value of long-term recordings and the strength and possibilities offered by continuous measurements from acoustic moorings. The results give ground for formulating future sampling programs that will further aid in interpretations of the behaviour of M. muelleri.

Acknowledgements. This study would not have been possible without the support of the Institute for Marine Research at Matre, which kindly made their infrastructure at Solheim (Masfjorden) available to us for this study, J. O. Fosse, T. A. Klevjer, as well as the crew and students from the University of Bergen and University of Oslo onboard the RVs 'H. Mosby' and 'T. Braarud'.

\section{LITERATURE CITED}

Aksnes DL, Aure J, Kaartvedt S, Magnesen T, Richard J (1989) Significance of advection for the carrying capacities of fjord populations. Mar Ecol Prog Ser 50:263-274

Axenrot T, Didrikas T, Danielsson C, Hansson S (2004) Diel patterns in pelagic fish behaviour and distribution observed from a stationary, bottom-mounted, and upwardfacing transducer. ICES J Mar Sci 61:1100-1104 
Bagøien E, Kaartvedt S, Aksnes DL, Eiane K (2001) Vertical distribution and mortality of overwintering Calanus. Limnol Oceanogr 46:1494-1510

Baliño BM, Aksnes DL (1993) Winter distribution and migration of the sound scattering layers, zooplankton and micronekton in Masfjorden, western Norway. Mar Ecol Prog Ser 102:35-50

> Benoit-Bird KJ, Au WWL, Wisdom DW (2009) Nocturnal light and lunar cycle effects on diel migration of micronekton. Limnol Oceanogr 54:1789-1800

Bevelhimer MS, Adams SM (1993) A bioenergetics analysis of diel vertical migration by Kokanee salmon, Oncorhynchus nerka. Can J Fish Aquat Sci 50:2336-2349

Bjelland O (1995) Life-history tactics of two fjordic populations of Maurolicus muelleri. Cand Scient (=MSc) thesis, University of Bergen

> Clark CW, Levy DA (1988) Diel vertical migrations by juvenile sockeye salmon and the antipredation window. Am Nat 131:271-290

> Cohen JH, Forward RB Jr (2009) Zooplankton diel vertical migration - a review of proximate control. Oceanogr Mar Biol 47:77-110

> Didrikas T, Hansson S (2009) Effects of light intensity on activity and pelagic dispersion of fish: studies with a seabed-mounted echosounder. ICES J Mar Sci 66:388-395

Dypvik E (2010) Invers døgnvandring og fødebiologi hos nordlig lysprikkfisk (Benthosema glaciale) i Masfjorden. MSc thesis, University of Oslo

Eggers DM (1978) Limnetic feeding behavior of juvenile sockeye salmon in lake Washington and predator avoidance. Limnol Oceanogr 23:1114-1125

Engås A, Skeide R, West CW (1997) The 'MultiSampler': a system for remotely opening and closing multiple codends on a sampling trawl. Fish Res 29:295-298

Falk-Petersen IB, Falk-Petersen S, Sargent JR (1986) Nature, origin and possible roles of lipid deposits in Maurolicus muelleri (Gmelin) and Benthosema glaciale (Reinhart) from Ullsfjorden, northern Norway. Polar Biol 5:235-240

Forward RB Jr, Hettler WF (1992) Effects of feeding and predator exposure on photoresponses during diel vertical migration of brine shrimp larvae. Limnol Oceanogr 37:1261-1270

Frank TM, Widder EA (2002) Effects of a decrease in downwelling irradiance on the daytime vertical distribution patterns of zooplankton and micronekton. Mar Biol 140: 1181-1193

Giske J, Aksnes DL (1992) Ontogeny, season and trade-offs: vertical distribution of the mesopelagic fish Maurolicus muelleri. Sarsia 77:253-261

Giske J, Aksnes DL, Balino BM, Kaartvedt S and others (1990) Vertical distribution and trophic interactions of zooplankton and fish in Masfjorden, Norway. Sarsia 75: 65-81

Gjøsæter J (1981) Life history and ecology of Maurolicus muelleri (Gonostomatidae) in the Norwegian waters. Fiskeridir Skr (Havunders) 17:109-131

Goodson MS, Giske J, Rosland R (1995) Growth and ovarian development of Maurolicus muelleri during spring. Mar Biol 124:185-195

Hamre LA (1999) Growth and mortality of Maurolicus muelleri (Gmelin): Do parasites matter? Cand Scient (=MSc) thesis, University of Bergen

Hays GC, Kennedy H, Frost BW (2001) Individual variability in diel vertical migration of a marine copepod: why some individuals remain at depth when others migrate. Limnol Oceanogr 46:2050-2054

> Heath MR (1999) The ascent migration of Calanus finmarchicus from overwintering depths in the Faroe-Shetland Channel. Fish Oceanogr 8:84-99

Hulley PA, Prosch RM (1987) Mesopelagic fish derivatives in the southern Benguela upwelling region. S Afr J Mar Sci 5:597-611

Kaartvedt S (1996) Habitat preference during overwintering and timing of seasonal vertical migration of Calanus finmarchicus. Ophelia 44:145-156

Kaartvedt S, Aksnes DL, Aadnesen A (1988) Winter distribution of macroplankton and micronekton in Masfjorden, western Norway. Mar Ecol Prog Ser 45:45-55

Kaartvedt S, Knutsen T, Holst JC (1998) Schooling of the vertically migrating mesopelagic fish Maurolicus muelleri in light summer nights. Mar Ecol Prog Ser 170: 287-290

> Kaartvedt S, Torgersen T, Klevjer TA, Røstad A, Devine JA (2008) Behavior of individual mesopelagic fish in acoustic scattering layers of Norwegian fjords. Mar Ecol Prog Ser 360:201-209

Kaartvedt S, Røstad A, Klevjer T, Staby A (2009) Use of bottom-mounted echo sounders in exploring behavior of mesopelagic fishes. Mar Ecol Prog Ser 395:109-118

Klevjer TA, Kaartvedt S (2006) In situ target strength and behaviour of northern krill (Meganyctiphanes norvegica). ICES J Mar Sci 63:1726-1735

Kristoffersen JB, Salvanes AGV (1998) Life history of Maurolicus muelleri in fjordic and oceanic environments. J Fish Biol 53:1324-1341

Levy DA (1990a) Reciprocal diel vertical migration behaviour in planktivores and zooplankton in British Columbia lakes. Can J Fish Aquat Sci 47:1755-1764

Levy DA (1990b) Sensory mechanism and selective advantage for diel vertical migration in juvenile sockeye salmon, Oncorhynchus nerka. Can J Fish Aquat Sci 47: 1796-1802

Lopes PC (1979) Eggs and larvae of Maurolicus muelleri (Gonostomatidae) and other fish eggs and larvae from tow fjords in western Norway. Sarsia 64:199-210

Love RH, Fisher RA, Wilson MA, Nero RW (2004) Unusual swimbladder behavior of fish in the Cariaco Trench. Deep-Sea Res I Oceanogr Res Pap 51:1-16

> Mehner T (2006) Individual variability of diel migrations in European vendance (Coregonus albula) explored by stationary vertical hydroacoustics. Ecol Freshw Fish 15: 146-154

Neilson JD, Perry RI (1990) Diel vertical migrations of marine fishes: an obligate or facultative process? Adv Mar Biol 26:115-167

Onsrud MSR, Kaartvedt S (1998) Diel vertical migration of the krill Meganyctiphanes norvegica in relation to physical environment, food and predators. Mar Ecol Prog Ser 171:209-219

> Pearre S Jr (2003) Eat and run? The hunger satiation hypothesis in vertical migration: history, evidence and consequences. Biol Rev Camb Philos Soc 78:1-79

Perry RI, Neilson JD (1988) Vertical distributions and trophic interactions of age-0 Atlantic cod and haddock in mixed and stratified waters of Georges Bank. Mar Ecol Prog Ser 49:199-214

> Rasmussen OI, Giske J (1994) Life-history parameters and vertical distribution of Maurolicus muelleri in Masfjorden in summer. Mar Biol 120:649-664 
Ringelberg J (1991) A mechanism of predator-mediated induction of diel vertical migration in Daphnia hyaline. J Plankton Res 13:83-89

Roe HSJ (1983) Vertical distributions of euphausiids and fish in relation to light intensity in the north-eastern Atlantic. Mar Biol 77:287-298

Rosland R (1997) Optimal responses to environmental and physiological constraints: evaluation of a model for a planktivore. Sarsia 82:113-128

Rosland R, Giske J (1994) A dynamic optimization model of the diel vertical distribution of a pelagic planktivorous fish. Prog Oceanogr 34:1-43

Rosland R, Giske J (1997) A dynamic model for the life history of Maurolicus muelleri, a pelagic planktivorous fish. Fish Oceanogr 6:19-34

Salvanes AGV, Nordeide JT (1993) Dominating sublittoral fish species in a west Norwegian fjord and their trophic links to cod (Gadus morhua L.). Sarsia 78:221-234

Scheuerell MD, Schindler DE (2003) Diel vertical migration by juvenile sockeye salmon: empirical evidence for the antipredation window. Ecology 84:1713-1720

Southward AJ, Barrett RL (1983) Observations on the vertical distribution of zooplankton, including postlarval teleosts, off Plymouth in the presence of a thermocline and a chlorophyll-dense layer. J Plankton Res 5: 599-618

Srisomwong J (2009) Diel vertical migration and feeding pattern of M. muelleri in Masfjorden in late autumn. MSc

Editorial responsibility: Ivan Nagelkerken,

Nijmegen, The Netherlands thesis, University of Bergen

Staby A (2010) Seasonal dynamics in the vertical migration behaviour of mesopelagic fish. $\mathrm{PhD}$ dissertation, University of Bergen

Staby A, Aksnes DL (2011) Follow the light - diurnal and seasonal variations in vertical distribution of the mesopelagic fish Maurolicus muelleri. Mar Ecol Prog Ser 422: 265-273

> Tarling GA, Jarvis T, Emsley SM, Matthews JBL (2002) Midnight sinking behaviour in Calanus finmarchicus: a response to satiation or krill? Mar Ecol Prog Ser 240: 183-194

Torgersen T, Kaartvedt S (2001) In situ swimming behaviour of individual mesopelagic fish studied by split-beam echo target tracking. ICES J Mar Sci 58:346-354

Vogel JL, Beauchamp DA (1999) Effects of light, prey size, and turbidity on reaction distances of lake trout (Salvelinus namaycush) to salmonid prey. Can J Fish Aquat Sci 56:1293-1297

> Widder EA, Frank TM (2001) The speed of an isolume: a shrimp's eye view. Mar Biol 138:669-677

Williams A, Koslow JA (1997) Species composition, biomass and vertical distribution of micronekton over the midslope region off southern Tasmania, Australia. Mar Biol 130:259-276

Wurtsbaugh WA, Neverman D (1988) Post-feeding thermotaxis and daily vertical migration in a larval fish. Nature 333:846-848

Submitted: November 5, 2010; Accepted: August 23, 2011

Proofs received from author(s): October 22, 2011 